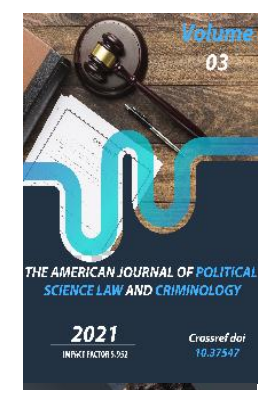

\title{
Issues Of Improving The Legal Basis Of The Institute Of Public Control In The Courts
}

\author{
Murodjon Abdumutal Oglu Shermatov \\ Basic Doctoral Student Of The Higher School Of Judges Under The Supreme Council Of Judges \\ Of The Republic Of Uzbekistan
}

Journal Website:

http://theamericanjour

nals.com/index.php/taj

psic

Copyright: Original

content from this work

may be used under the

terms of the creative

commons attributes

4.0 licence.

\section{ABSTRACT}

The scientific article examines the principles and problems of open and transparent functioning of the courts, ensuring public participation in open court proceedings as one of the ongoing reforms in the judicial system. Suggestions and recommendations have been developed for our national legislation.

\section{KEYWORDS}

Transparency of court proceedings, open court session, public control, open court hearing, closed and partially closed court session, judicial body.

\section{INTRODUCTION}

The purpose of the judicial reforms initiated by the President of the Republic of Uzbekistan Sh.M.Mirziyoev is, first of all, to strengthen the image of the judiciary as an important guarantee of effective protection of human rights, freedoms and legitimate interests, to ensure true independence of the judiciary and to increase its role in building civil society. The Action Strategy for the further development of the Republic of Uzbekistan also identifies important tasks in such a paragraph as
"Priorities for ensuring the rule of law and further reform of the judicial system." ${ }^{1}$. In particular, research in the areas of establishing public control over the administration of justice, improving the powers of the

1 Decree of the President of the Republic of Uzbekistan, dated February 7, 2017 No PD-4947 "On the Action Strategy for further development of the Republic of Uzbekistan." // Collection of Legislation of the Republic of Uzbekistan, 2017, No. 6, Article 70. 
appointment and dismissal of chairmen and judges is very important.

The issues of protection of human rights, prevention of violations of human rights and freedoms, administration of justice and further deepening of democratic reforms in the field are important. These issues are becoming increasingly important, especially in the context of deepening globalization. In this direction, work is underway to strengthen the role of the judiciary in the system of power, to ensure the independence of the judiciary. In short, in solving all the problems and tasks before us, "the state should serve the interests of the people, not the interests of the state."

It should be noted that the concept of "judicial system" is interpreted differently by scholars. For example, according to S.Razumov: "Judicial system is a set of all courts that operate independently of the legislature and the executive, are part of a single judicial system and have common tasks, principles of structure and operation of justice, and exercise judicial power independently through justice." 2

According to D.Karpov, the judicial system of the state consists of courts that deal with constitutional, civil, criminal, administrative cases, thereby using the legal procedures established by law and performing only the functions of resolving social conflicts. ${ }^{3}$ These

2 Разумов С.Л. Понятие судебной системы / Судебная система России. - М., 2000. - С. 114.

3 Карпов Д.В. Проблемы конституционноправового гарантирования правозащитной функции судебной власти в Российской Федерации: Автореф. дис. Канд. юрид. наук. Н. Новгород, 2012. concepts also apply to the judicial system of Uzbekistan.

The legal documents adopted by the courts in the performance of their duties are the final decision-making body on all aspects of the case, and the documents adopted by them are of interest to the public. The judiciary should be an institution that establishes justice. Also, courts must make lawful, fair, and reasoned decisions. Confidence in the judiciary among the population should be high and this should be demonstrated on a regular basis. It should be noted that the role of the institution of public control in the judicial system is great, and improving their participation is an important factor.

The Decree of the President of the Republic of Uzbekistan dated July 13, 2018 "On measures to further improve the judicial system and increase confidence in the judiciary" 4 to improve the institution of public control in the courts has raised reforms in this area to a new level. According to the decree, the participation of public control institutions in the activities of the courts will be ensured, and the practice of mobile court hearings in mobile courts has reached a new level.

It is also necessary to cite the Resolution of the Supreme Court of the Republic of Uzbekistan dated February 21, 2020 "On ensuring the transparency of court proceedings and the right to receive information on the activities of the courts." 5

\footnotetext{
${ }^{4}$ National Database of Legislation, 21.01.2021, No. 06/21/6144/0052.

${ }^{5}$ Resolution of the Supreme Court of the Republic of Uzbekistan dated February 21, 2020 "On ensuring the transparency of court proceedings and the right to receive information on the activities of the courts." // https://lex.uz/docs/4751577
} 
The essence of this decision is that the transparency of court proceedings, timely and objective information to the public about the activities of the courts will increase the level of legal awareness in society. It is an important guarantee of the administration of justice, an effective means of ensuring public control over the judiciary and increasing public confidence in the judiciary.

That is, the purpose of the principle of transparency in the courts is to strengthen people's confidence in the judiciary, to ensure public control over the trial through the participation of the media in the trial. Therefore, the principle of transparency in the literature means the participation of all persons, including representatives of the media, in the consideration of their cases in court. The principle of transparency allows for the publication of court proceedings in the media, in particular in newspapers, magazines, broadcasting on radio and television, and, if necessary, in mobile courts with the participation of representatives of public organizations and labor unions.

It should be noted that the principles of transparency and openness applied to the judiciary are reflected in a number of international instruments governing the organizational and legal issues of the judiciary as one of the important manifestations of the right to a fair trial. For example, Articles 10, 11, 19, 29 of the Universal Declaration of Human Rights ${ }^{6}$, Articles 14 and 19 of the International Covenant on Civil and Political Rights ${ }^{7}$, Article

6 Universal Declaration of Human Rights // https://www.un.org/en/about-us/universaldeclaration-of-human-rights

${ }^{7}$ International Covenant on Civil and Political Rights
13 of the Convention on the Rights of the Child $^{8}$ and other documents. In the process of building a new Uzbekistan, special attention is paid to reforming the judiciary and improving its constitutional and legal framework, as well as ensuring the transparency of the judiciary.

At the same time, the process of informatization of the judicial system in the country is being carried out gradually. The use of modern information technologies in the judiciary, in particular, the introduction of electronic document management systems, the creation and implementation of judicial information systems, the provision of services to citizens through websites is the result of ongoing reforms in the judiciary.

The involvement of modern information technologies in the judicial system of the Republic of Uzbekistan is also one of the main directions of the ongoing reforms in the judicial system of the country. This task is also set out in the Action Strategy for the five priority areas of development of the Republic of Uzbekistan for 2017-2021.

In order to ensure timely resolution of appeals, eliminate red tape, ensure openness and transparency of the courts, as well as further strengthen cooperation in this area through the introduction of modern information technologies and new types of interactive judicial services, the President of the Republic of Uzbekistan signed a decree on September 3, 2020 "On measures to digitize

/I

https://www.ohchr.org/en/professionalinterest/pages/ ccpr.aspx

8 Convention on the Rights of the Child // https://www.ohchr.org/en/professionalinterest/pages/ crc.aspx 
the activities of the judiciary" ${ }^{\prime 2}$ which will ensure that the activities of the courts meet modern requirements.

The courts were tasked with the introduction of modern information technologies, in particular, electronic document exchange, the development and implementation of information resources and information systems in the field, the provision of interactive services in the judiciary.

On this basis, as a result of the introduction of modern information and communication technologies in the courts, the procedure for remote access to courts, participation in court hearings using videoconferencing, the mechanism of distribution of cases among judges in the court of first instance and the publication of court decisions on the Internet execution systems were introduced. It can also be seen through these systems that the public is able to monitor, review and receive information electronically about the activities of the courts and the documents they receive.

In addition, information systems of government agencies and organizations are gradually being connected to the court information system in order to further expand the exchange of electronic data with ministries, agencies and other organizations to ensure the speedy receipt of information necessary for the administration of justice in the courts. This will reduce the time required to obtain the documents required from the institutions during the proceedings, and will eliminate the unnecessary hassle of the parties.

\footnotetext{
${ }^{9}$ National Database of Legislation, 04.09.2020, No. 07/20/4818/1255
}

That is, by sending the information provided by the courts to government agencies and organizations in electronic form, the information and documents required in the process of a particular case are obtained by the courts directly from government agencies and organizations in electronic form without disturbing citizens.

There was also a mechanism for distributing lawsuits, complaints, and appeals between judges in administrative, economic, civil, and criminal cases under the e-judicial system introduced in the courts. However, there was no distribution of cases to judges using an automated information system in appellate or cassation proceedings when a complaint or protest was lodged in an administrative, economic, civil or criminal case before a court of first instance.

Now, when considering cases in the courts of appeal and cassation, the workload of judges is taken into account, and the distribution of cases among judges electronically prevents the influence of those interested in the outcome of the trial. It is also possible to monitor this distribution system directly by the public. In turn, this increases citizens' confidence in justice.

Today, modern information and communication technologies introduced in the activities of the courts are limited to video conferencing of court hearings, the publication of court decisions on the Internet. This requires the judiciary to have sufficient technological and human resources to ensure the effective introduction of modern information technologies and their uninterrupted operation. 
At the same time, based on the analysis of foreign experience, it should be noted that in district and city courts it is expedient to create a position of the court administration on the reception of citizens' appeals and public relations and to provide 1 state unit. This directly ensures the true independence and impartiality of the judge.

In conclusion, ensuring the participation of the institute of public control in the activities of the courts ensures a lawful, reasoned and fair court decision on the case. It is also advisable to avoid restricting the participation of public bodies in court proceedings. To this end, it would be expedient for the relevant qualification commissions of judges to strictly consider the appeals of the public in cases of restriction of public participation by the courts directly and to establish issues of responsibility in respect of them. At the same time, it is necessary to widely introduce modern technologies in the work of courts and improve their skills. In addition, in order to ensure the independence and impartiality of judges in district and city courts, it will be necessary to introduce a judicial administration staff to work with the public and citizens.

\section{REFERENCES}

1. Decree of the President of the Republic of Uzbekistan, dated February 7, 2017 No PD4947 "On the Action Strategy for further development of the Republic of Uzbekistan." // Collection of Legislation of the Republic of Uzbekistan, 2017, No. 6, Article 70.

2. Разумов С.Л. Понятие судебной системы, Судебная система России. - М., 2000. - С. 114.
3. Карпов А.В. Проблемы конституционноправового гарантирования правозащитной функции судебной власти в Российской Федерации: Автореф. дис. Канд. юрид. наук. Н. Новгород, 2012.

\section{Normative and legal documents}

4. Universal Declaration of Human Rights // https://www.un.org/en/about-us/universaldeclaration-of-human-rights.

5. International Covenant on Civil and Political Rights

II

https://www.ohchr.org/en/professionalinte rest/pages/ccpr.aspx.

6. National Database of Legislation, 21.01.2021, No. 06/21/6144/0052.

7. National Database of Legislation, 04.09.2020, No. 07/20/4818/1255.

8. Resolution of the Supreme Court of the Republic of Uzbekistan dated February 21, 2020 "On ensuring the transparency of court proceedings and the right to receive information on the activities of the courts." // https://lex.uz/docs/4751577.

9. Convention on the Rights of the Child // https://www.ohchr.org/en/professionalinte rest/pages/crc.aspx. 